\title{
Flaggermusen
}

Organ for Norsk forening for ultralyddiagnostikk

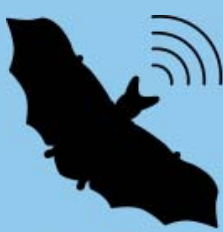

nfud.no

\section{Euroson i Lubljana 2017}

Årets Euroson ble holdt i Ljubljana, Slovenia 22. til 24. september. Som vanlig når det ikke koordineres med Dreiländertreffen, kom det færre deltagere, men arrangementet gikk uten større problemer. Kim Nylund representerte NFUD ved møtet i Board of directors og kunne bevitne at flere norske representanter ble valgt inn i viktige posisjoner. Erlend Valestrand ble valgt inn i den nydannete Student committee mens Ragnar Sande "tok over» etter Pepe Salvesen i Security committee. Roald Havre ble gjenvalgt til Publication committee. Odd Helge Gilja gikk over i rollen som Past president mens Paul Sidhu fra England ble EFSUMBs nye president.

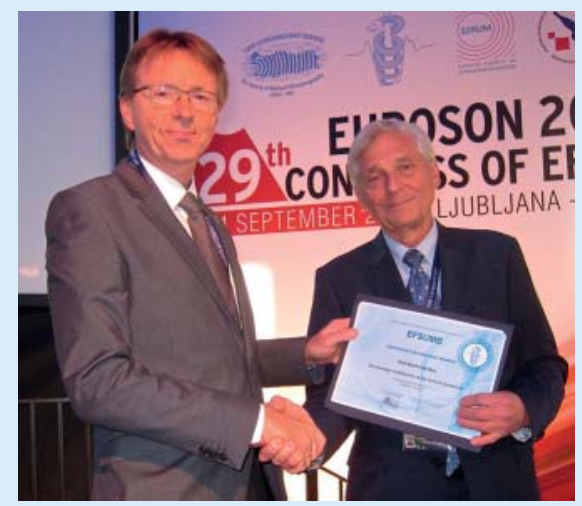

Sturla Eik-Nes mottar beviset på sitt æresmedlemsskap fra Odd Helge Gilja.
I tillegg til dette stilte Charlotte Skorpen på vegne av NFUD som Norges Young Investigator med sitt innlegg "The introduction of POCUS for medical students, emergency medicine and intensive care physicians in Romania." Det var dessuten stor stas da Sturla Eik-Nes ble hedret som nytt æresmedlem i EFSUMB.

Til neste år vil Euroson bli hold $\mathrm{i}$ Poznan, Polen, fra 6. til 9. september og således vil reiseveien bli noe kortere, men i 2020 kan den norske delegasjon spare store penger på reisebudsjettet. NFUD i samarbeid med Nasjonalt kompetansesenter for gastroenterologisk ultrasonografi fikk nemlig antatt sin søknad til å arrangere Euroson i Bergen. 